\title{
Pengaruh Faktor Fisik Terhadap Faktor Kognitif Terkait Penerimaan Individu Terhadap Teknologi
}

\author{
ANFAZUL FARIDATUL AZIZAH \\ Sistem Informasi/Fakultas Teknologi Informasi dan Industri \\ Institut Teknologi Telkom Surabaya \\ anfazul.azizah@ittelkom-sby.ac.id
}

\begin{abstract}
ABSTRAK
Penelitian ini bertujuan untuk mengetahui pengaruh faktor fisik terhadap faktor cognitive. Fisik disini adalah panca indera yaitu mata, sedangkan cognitive disini adalah kinerja otak. Dengan mengetahui pengaruh tersebut, proses kinerja otak akan lebih baik jika didukung oleh tampilan warna latar belakang yang sesuai.Penelitian ini menggunakkan pengujian website dan alat "Neurosky Mindwave".Hasil dari penelitian ini diharapkan dapat memberikan masukan bagi perusahaan dalam menciptakan sebuah produk teknologi dengan mempertimbangkan dampaknya terhadap kinerja otak.
\end{abstract}

Kata kunci: Fisik, kognitif, neurosky mindwave, warna, latar belakang

\begin{abstract}
This study aims to determine the effect of physical factors on cognitive factors. Physical here are the five senses, namely the eye, while cognitive here is the performance of the brain. By knowing the influence, the process of brain performance will be better if supported by the appearance of the appropriate background color. This research using website testing and Neurosky Mindwave tools. The results of this study are expected to provide input for companies in creating a technology product by considering the impact on brain performance.
\end{abstract}

Keywords : Physical, cognitive, neurosky mindwave, color, background. 


\section{PENDAHULUAN}

Setiap manusia tentunya mempunyai panca indera yang bermanfaat dalam mendukung aktivitas sehari - hari. Mata merupakan alat panca indera untuk melihat. Dari mata, informasi dapat dilihat dan diproses secara langsung ke otak. Hal ini sejalan dengan penelitian(Caro, Tentori, Martinez-Garcia, \& Alvelais, 2017) desain"easy to use"dan" useful" dalam mendukung anak-anak dengan autisme parah untuk melatih koordinasi mata-tubuh sehingga tetap fokus selama latihan (Caro, Tentori, Martínez-García, \& Zavala-Ibarra, 2015). Ini disebabkan ketika tampilan di layar monitor sesuai dengan panca indera, maka kinerja otak akan lebih bagus. Penelitian lainnya yaitu exergames juga dikembangkan untuk menumbuhkan komunikasi dan interaksi sosial (Bernardini, Porayska-Pomsta, \& Smith, 2014), (Bhattacharya, Gelsomini, Pérez-Fuster, Abowd, \& Rozga, 2015), (Uzuegbunam, Wong, Cheung, \& Ruble, 2015), dan untuk mengajar pengembangan anak seperti meniru postur dan menyentuh benda (Casas, Herrera, Coma, \& Fernández, 2012).

Berdasarkan hasil dari penelitian sebelumnya iCAN, sistem berbasis tablet (Chien et al., 2015)juga berhasil meningkatkan konsentrasi. (Boyd et al., 2016) merancang SayWAT, teknologi bantuan yang dapat dipakai untuk menyediakan umpan balik bagi orang dewasa selama tatap muka percakapan. Penelitian berikutnya ((Rapp, Cena, Castaldo, Keller, \& Tirassa, 2018) mempertimbangkan desain dari perspektif anak autis untuk mendukung pendekatan cognitive. Hal ini dimaksudkan jika tampilan desain sesuai dengan panca indera anak autis melalui mata, tentunya secara cognitive akan lebih mudah diterima. Sehingga pada penelitian ini dibahas mengenai pengaruh faktor physical (mata) dan cognitive (otak) terhadap keputusan individu dalam menerima sebuah teknologi.

Faktor physical atau yang lebih dikenal dengan faktor ergonomics adalah ilmu manusia yang menggabungkan penelitian mekanik tubuh manusia dan keterbatasan fisik dengan industri psikologi.= Teknologi yang secara fisik diterima adalah teknologi yang sesuai dengan panca indera. Sedangkan faktor cognitive adalah segala sesuatu yang mempunyai pengaruh terhadap daya kinerja otak dalam penerimaan sebuah teknologi. Teknologi yang secara cognitive diterima adalah teknologi yang membuat kerja otak berkurang dan semakin minim membutuhkan daya ingat. HCI (Human Computer Interaction) diperlukan dalam ilmu cognitive untuk mempermudah pemahaman sistem dan manusia.

Pada penelitian ini peserta dipasangkan alat "Neurosky Mindwave" untuk melihat aktivitas otak. Selanjutnya pada proses pengolahan data digunakan GSCA (Generalized Structured Component Analysis) untuk mengetahui hubungan faktor fisik terhadap faktor cognitive. GeSCAmerupakan metode analisis yang powerfull yaitu data tidak harus berdistribusi normal multivariate dan sample tidak harus besar. Hasil dari penelitian ini diharapkan dapat memberikan masukan bagi perusahaan IT dalam menciptakan sebuah produkyang sesuai dengan keterbatasan fisik manusia dan penulis ingin memberikan kontribusi bagi dunia pendidikan sehingga para guru dan orang tua dapat memberikan inovasi dalam pengajaran dengan mempertimbangkan faktor fisik dan cognitive sehingga dapat meningkatkan kinerja otak anak didik.

\section{METODE PENELITIAN}

Tahapan-tahapan yang digunakan dalam membahas permasalahan yang ada pada penelitian ini. Secara global, ditunjukkan seperti pada Gambar 1 berikut. 


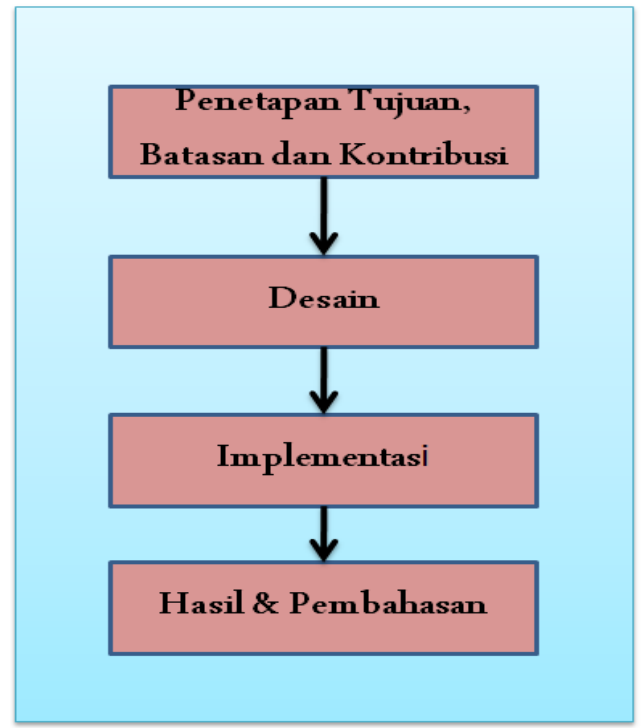

Gambar 1 Metode Penelitian

\subsection{Penetapan Tujuan, Batasan dan Kontribusi}

\subsubsection{Penetapan tujuan}

Penelitian ini bertujuan untuk mengetahui pengaruh faktor fisik terhadap faktor cognitive. Faktor fisik disini adalah panca indera manusia sedangkan cognitive adalah kinerja otak manusia.

\subsubsection{Batasan}

Penelitian ini dilakukan oleh mahasiswa lintas angkatan dengan total 100 peserta. Tidak buta warna dan masing - masing peserta memiliki ketajaman mata. Untuk lebih lengkapnya, karakteristik responden dapat dilihat pada Tabel 1 berikut.

Tabel 1 Karakteristik Responden

\begin{tabular}{|l|l|l|l|}
\hline No & \multicolumn{1}{|c|}{ Karakteristik } & \multicolumn{1}{|c|}{ Jumlah (Peserta) } & \multicolumn{1}{|l|}{ Presentase \% } \\
\hline 1 & Usia & 25 & $25 \%$ \\
\hline & $18-19$ tahun & 25 & $25 \%$ \\
\hline & $19-20$ tahun & 25 & $25 \%$ \\
\hline & $20-21$ tahun & 25 & $25 \%$ \\
\hline & $21-22$ tahun & \multicolumn{2}{|l}{} \\
\hline 2 & Jenis Kelamin & 50 & $50 \%$ \\
\hline & Laki - laki & 50 & $50 \%$ \\
\hline & Perempuan &
\end{tabular}

Selama prosesnya, penelitian ini melibatkan 100 orang responden. Namun setelah melalui proses rekap, didapatkan data responden lengkap sejumlah 91 orang. 


\subsubsection{Kontribusi}

Penelitian ini dapat memberikan masukan bagi produsen teknologi sehingga dapat menciptakan produk dengan mempertimbangkan keterbatasan fisik manusia serta memiliki dampak positif yaitu teknologi yang digunakan dapat meningkatkan kinerja otak manusia dengan memasukkan faktor fisik dan cognitive.

\subsection{Desain}

Pada tahapan ini penulis mengadopsi penelitian kombinasi teks dan warna latar belakang di layar komputer yang berdampak pada kinerja tugas (Tharangie, Irfan, Marasinghe, \& Yamada, 2008),(Jang, Kim, \& Yi, 2007). Sebuah studi awal oleh (Yamazaki \& Eto, 2011) menunjukkan bahwa nilai rata-rata untuk computer-based english grammar tests dengan latar belakang biru dan light blue secara signifikan lebih tinggi dari pada tes dengan berlatar belakang putih. Sehingga dalam penelitian ini ditentukan hipotesis yaitu :

\section{H1. Faktor physical dapat mempengaruhi faktor cognitive pengguna.}

\section{Pelaksanaan Uji Coba}

Pada penelitian ini, dilakukan percobaan untuk melihat bagaimana warna latar belakang web-based tests (WBTs) dapat mempengaruhi kinerja otak pengguna. Proses pengujian pada penelitian ini di lakukan dengan 2 studi percobaan. Studi pertama dilakukan dengan penghitungan simbol (berupa bintang, segitiga, dan lingkaran) di layar komputer dengan latar belakang biru dan putih. Untuk kedua warna latar belakang, teks dan simbol disajikan dalam warna hitam seperti yang dapat dilihat pada Gambar 2.
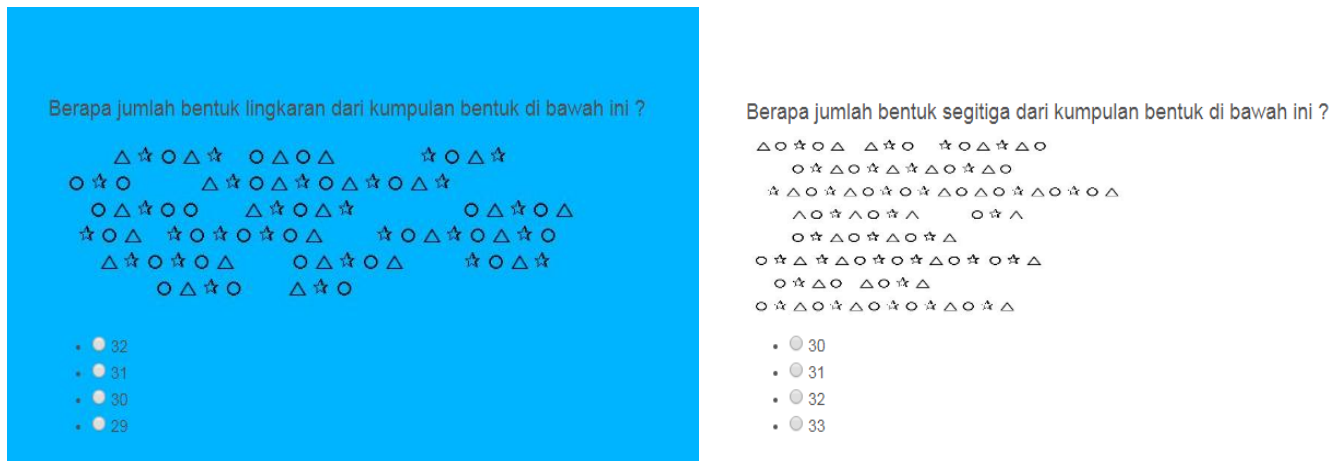

Gambar 2 Uji Coba Website dengan warna latar belakang biru dan putih

Sedangkan pada studi yang kedua, peserta diminta untuk menjawab 14 pertanyaan dalam skala Likert 5 berdasarkan faktor fisik dan faktor cognitive. Pada hipotesi sini, peserta juga di pasangkan alat "Neurosky Mindwave" untuk melihat aktivitas otak yang ditampilkan dalam bentuk gelombang pada layar komputer seperti yang dapat dilihat pada Gambar 3 dan Gambar 4. Selanjutnya pada proses pengolahan data di gunakan GSCA untuk mengetahui hubungan faktor fisik terhadap faktor cognitive. 


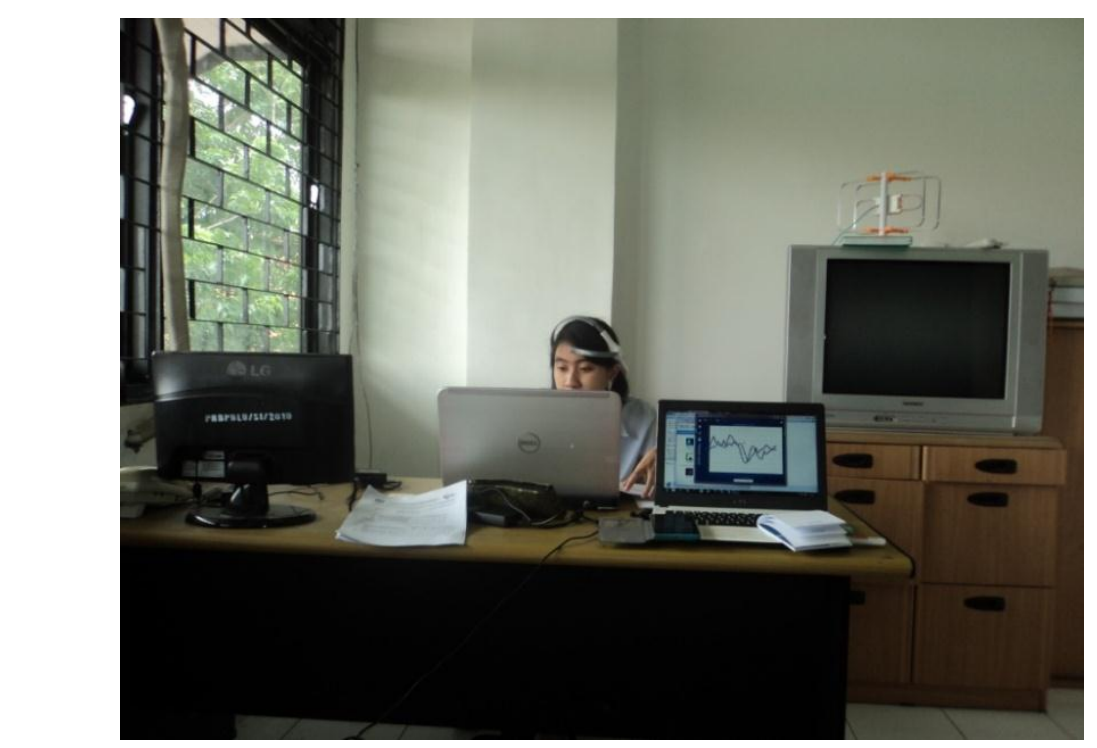

Gambar 3 Aktifitas responden pada saat pengujian simbol beserta penggunaan alat "Neurosky Mindwave"

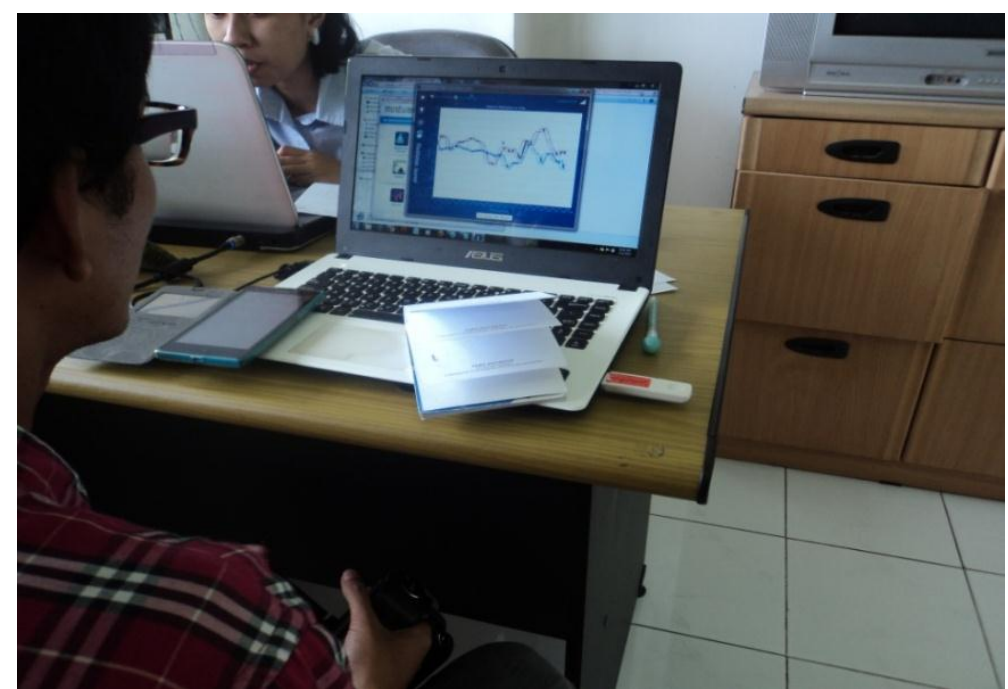

Gambar 4 Tampilan pada layar komputer penggunaan alat "Neurosky Mindwave"

\subsection{Implementasi}

Pada tahapan implementasi terdiri dari beberapa tahapan sebagai berikut :

\subsubsection{Pengembangan Model dan Rancangan Penelitian}

Dalam rangka menguji dan menganalisis model sesuai dengan tujuan yang telah ditetapkan, maka penelitian yang dirancang kali ini berupa penelitian eksplanatif, kuantitatif dan kualitatif. Penelitian eksplanatif adalah suatu penelitian yang bertujuan untuk mendapatkan penjelasan mengenai hubungan (kausalitas) antar variabel, melalui pengujian hipotesis. Dalam hal ini melakukan kajian terkait untuk mengetahui hubungan dari variabel faktor fisik, cognitive terhadap keputusan individu dalam menerima sebuah teknologi.

Penelitian ini menggunakkan pendekatan kuantitatif, yakni dengan mengukur fenomena yang diteliti, dengan menggali data dari hasil kuesioner. Sedangkan penelitian menggunakkan pendekatan kualitatif, yakni dengan melakukan teknik 
wawancara dengan responden. Kriteria responden yaitu terdiri dari mahasiswa dan mahasiswi yang tidak satupun responden mengalami buta warna atau bisa dikatakan semua peserta memiliki penglihatan yang tajam.

\subsubsection{Penyusunan instrument penelitian dan pengukurannya}

Instrument penelitian yang digunakan dalam penelitian ini yaitu berupa daftar pertanyaan kuesioner yang dirancang sesuai dengan indikator dari variabel - variabel yang ada di dalam model konseptual seperti yang di tunjukkan pada Tabel 2. Skala Likert yang digunakan untuk mengukur atau menilai jawaban tiap item pernyataan dalam penelitian ini menggunakkan rentang nilai $1-5$, dimana semakin besar nilai menunjukkan jawaban yang semakin positif dan sebaliknya semakin kecil nilai menunjukkan jawaban yang semakin negative. Skala Likert 1-5 pada penelitian ini digunakan untuk mewakili persetujuan atau ketidaksetujuan responden dalam menjawab pernyataan yang diajukan dalam kuesioner.

Tabel 2 Variable dan Indikator

\begin{tabular}{|c|c|c|c|l|}
\hline $\begin{array}{c}\text { Fisik } \rightarrow \\
\text { Cognitive } \\
\text { Y2 }\end{array}$ & $\begin{array}{c}\text { Penglihatan } \\
\text { Y2.1 }\end{array}$ & $\begin{array}{c}\text { Kelelahan } \\
\text { mata } \\
\text { Y2.1.1 }\end{array}$ & 1 & Website tersebut membuat mata saya lelah. \\
\hline & & 2 & $\begin{array}{l}\text { Website tersebut membuat otot mata saya } \\
\text { tegang. }\end{array}$ \\
\hline & & 3 & $\begin{array}{l}\text { Website tersebut membuat gerakan mata } \\
\text { saya lebih aktif. }\end{array}$ \\
\hline & $\begin{array}{c}\text { Sharpness } \\
\text { Y2.1.2 }\end{array}$ & 4 & $\begin{array}{l}\text { Website tersebut membuat pupil mata saya } \\
\text { membesar. }\end{array}$ \\
\hline & & 5 & $\begin{array}{l}\text { Website tersebut meningkatkan ketajaman } \\
\text { mata saya. }\end{array}$ \\
\hline
\end{tabular}

\section{Faktor Fisik $\rightarrow$ Cognitive (Y2)}

Pada variabel Y2 penelitian ini yakni faktor fisik yang ditujukan untuk mendapatkan data cognitive dalam pengujian. Fisik di sini adalah fisik panca indera manusia bisa berupa penglihatan, otot, pendengaran, dll. Fisik pada variabel ini digunakan untuk mengukur kinerja otak manusia atau biasa yang dikenal dengan faktor cognitive. Pengujian di faktor Y2 ini, responden juga di berikan tes perhitungan simbol (lingkaran, bintang dan segitiga) dengan 2 warna latar belakang yaitu warna biru dan putih. Kemudian di tuangkan berupa daftar pernyataan di kuesioner. Tujuannya adalah untuk melihat seberapa besar pengaruhnya penglihatan manusia dengan 2 warna latar belakang yang berbeda (dalam hal ini warna biru dan putih) apakah berpengaruh terhadap kinerja otak manusia.

\subsubsection{Pengumpulan data dan analisa data}

Tempat penelitian untuk pengumpulan data di desain sesuai rancangan studi penelitian. Setelah melakukan studi pendahuluan maka peneliti mulai mengatur jadwal untuk penelitian tersebut. Apabila dalam prosesnya data yang dikumpulkan mengalami masalah (responden tidak hadir atau responden mengundurkan diri) maka dapat digantikan dengan responden yang lain. Dengan syarat dalam pengujian tidak boleh mempunyai profil responden yang double (sama). Data penelitian juga didukung dari referensi buku yang berkaitan, internet dan sumber lain yang relevan dengan materi penelitian ini. 


\subsection{Hasil dan Pembahasan}

Hasil survei yang dilakukan dalam penelitian ini sesuai dengan penelitian sebelumnya yaitu hasil dari observasi dan analisis perubahan konsentrasi $\mathrm{Hb}$ (hemoglobin) di otak menunjukkan bahwa daerah otak yang berhubungan dengan proses linguistik lebih aktif apabila grammar questions dengan teks hitam ditampilkan pada latar belakang biru muda. Dalam penelitian sebelumnya juga, gambar NIRS (Nearinfrared Spectroscopy) perubahan konsentrasi $\mathrm{Hb}$ dalam otak subjek menunjukkan bahwa daerah otak yang berhubungan dengan gerakan mata (Muggleton, Juan, Cowey, Walsh, \& O'Breathnach, 2010) cenderung lebih aktif saat melakukan tugas dengan latar belakang warna putih dari pada saat melakukan tugas yang sama dengan berlatar belakang warna biru ( Yamazaki \& Eto, 2011), (Yamazaki \& Eto, 2012).

Measure of fit model pengukuran pada dasarnya digunakan untuk melihat tingkat validitas dan reabilitas dari setiap indikator reflekktif dan formatif. Pada indikator reflektif ukuran validitas dievaluasi berdasarkan convergent validity, dalam hal ini loading estimate antara 0,5 - 0,6 dianggap cukup atau bisa dikatakan dapat diterima dan jika signifikan $(\mathrm{p}<0,05)$ maka dianggap valid. Discriminant Validity dinilai dengan membandingkan nilai akar kuadrat dari average variance extracted (AVE). Jika AVE lebih besar dari variabel lainnya maka memiliki discriminant validity yang baik ( Hamid, Sami, \& Sidek, 2017).

Sedangkan pada indikator formatif ukuran validitas dievaluasi berdasarkan substantive contentnya, yaitu dengan melihat signifikansi dari weight, jika signifikan $(p<0,05)$ berarti valid. Berdasarkan hasil dari pengolahan data yang dilakukan dengan menggunakan GeSCA maka didapatkan nilai dari model pengukuran penelitian ini. Untuk lebih jelasnya dapat dilihat pada Tabel 3 di bawah ini.

Tabel 3. Model Pengukuran Fisik $\rightarrow$ Cognitive

\begin{tabular}{|c|c|c|c|c|c|c|c|c|c|}
\hline Variable & \multicolumn{3}{|c|}{ Loading } & \multicolumn{3}{|c|}{ Weight } & \multicolumn{3}{|c|}{ SMC } \\
\hline & Estimate & SE & CR & Estimate & SE & CR & Estimate & SE & $\mathbf{C R}$ \\
\hline Fisik & \multicolumn{9}{|c|}{ AVE $=1.000$, Alpha $=0.000$} \\
\hline Fisik & 1.000 & 0.000 & - & 1.000 & 0.000 & - & 1.000 & 0.000 & - \\
\hline Cognitive & \multicolumn{9}{|c|}{ AVE $=1.000$, Alpha $=0.000$} \\
\hline Cognitive & 1.000 & -nan & 0.0 & 1.000 & 0.000 & - & 1.000 & 0.000 & - \\
\hline
\end{tabular}

Variabel fisik memiliki validitas yang tinggi hal ini dapat dilihat dari indikatornya memiliki convergent validity yang baik dimana semua loading faktornya diatas 0,70 yang mana sesuai dengan persyaratan. Sedangkan variabel cognitive juga memiliki validitas yang tinggi, hal ini dapat dilihat dari indikatornya yang memiliki convergent validity baik dimana semua loading faktornya diatas 0,70 sesuai syarat sebelumnya.

Berdasarkan hasil pada Tabel 3, nilai akar kuadrat dari AVE variabel faktor fisik dan cognitive adalah 1. Sementara nilai korelasi antara konstruk lainnya yaitu 0,202. Karena nilai AVE dengan nilai konstruk lainnya lebih besar maka dapat dikatakan memiliki discriminant validity yang baik. Untuk lebih jelasnya nilai korelasi faktor cognitive dapat dilihat pada Tabel 4. 
Tabel 4. Correlations of Latent Variables (SE)

\begin{tabular}{|c|c|c|}
\hline \multicolumn{3}{|c|}{ Correlations of Latent Variables (SE) } \\
\hline & Fisik & Cognitive \\
\hline Fisik & 1 & $0.202(0.083) *$ \\
\hline Cognitive & $\oplus .202(0.083)^{*}$ & 1 \\
\hline
\end{tabular}

Reliabilitas yang baik adalah apabila nilai Cronbach Alpha $\geq 0,70$ dan nilai AVE $\geq 0,5$. Berdasarkan hasil yang telah didapat maka reliability untuk faktor fisik $\rightarrow$ cognitive di penelitian ini terbukti telah memenuhi syarat. Untuk lebih jelasnya dapat dilihat pada Tabel 5 sebagai berikut :

Tabel 5. Reliability Statistics

\begin{tabular}{rlrr}
\hline \multicolumn{3}{c}{ Reliability Statistics } \\
\hline Cronbach's Alpha & $\begin{array}{l}\text { Cronbach's Alpha Based on Standarized } \\
\text { Items }\end{array}$ & .821 & N of Items \\
.815 & & & 5 \\
\hline
\end{tabular}

\section{Evaluasi Model Struktural (Inner Mode)}

Untuk model ini, pada Tabel 6 terlihat adanya hubungan struktural antar variabel yang menunjukkan bahwa faktor fisik berpengaruh positif terhadap faktor cognitive dengan nilai koefisien sebesar 0,202 dan signifikan pada 0,05.

Tabel 6. Path Coefficients

\begin{tabular}{lccc}
\hline \multicolumn{3}{c}{ Path Coefficients } \\
\hline & Estimate & SE & CR \\
Fisik > Cognitive & 0.202 & 0.083 & 2.42 \\
CR* = significant at .05 level & & \\
\hline
\end{tabular}

Berdasarkan hasil yang ada pada Tabel 7 , nilai $r$ square cognitive 0,041 artinya bahwa variabilitas faktor cognitive dapat dijelaskan oleh faktor fisik $4,1 \%$ seperti dijelaskan pada Tabel 7 di bawah ini.

\section{Tabel 7. R Square of Latent Variable}

\begin{tabular}{lc}
\hline \multicolumn{2}{c}{ R Square of Latent } \\
Variable
\end{tabular}




\section{Hasil Aktivitas Otak}

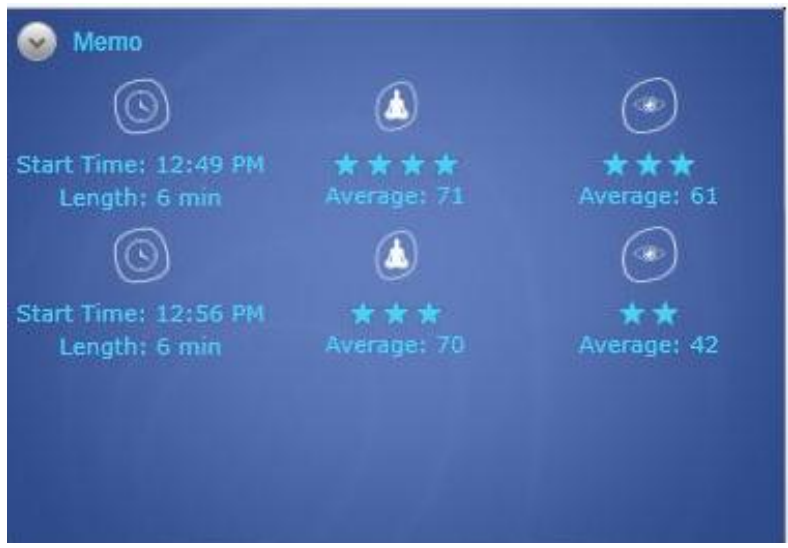

\section{Gambar 6 Hasil Perekaman Aktivitas Otak}

Dari gambar 6 di atas, terlihat ada dua hasil perekaman aktivitas otak pada window kecil di depan. Hasil bagian atas merupakan hasil perekaman pada saat responden mengerjakan web-based test dengan latar belakang berwarna biru, sedangkan hasil bagian bawah merupakan hasil perekaman pada saat responden mengerjakan webbased test dengan latar belakang berwarna putih. Untuk gambar sebelah kiri merupakan meditation dan untuk sebelah kanan merupakan attention. Pada gambar diatas, dapat dilihat rata-rata dari gelombang meditation dan attention. Responden diatas memiliki rata-rata gelombang meditation dari aktivitas otak di skala 71, dan rata-rata gelombang attention dari aktivitas otak di skala 61 .

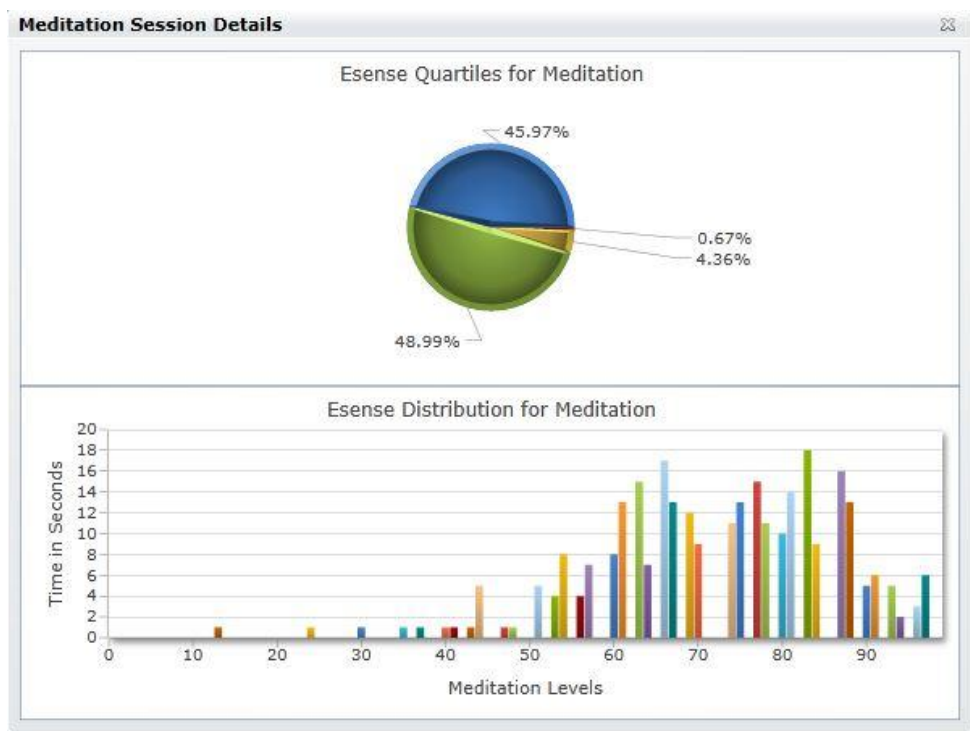

\section{Gambar 7 Hasil Resume Gelombang Meditation}

Pada Gambar 7 di atas, terlihat bahwa aktivitas otak paling sering berada di rentang skala 50-75 sebesar 48,99\%. Aktivitas otak dari responden berada di titik 83 sebanyak 18 detik. Dari keseluruhan responden, didapatkan hasil rata-rata dari gelombang otak seperti pada Tabel 8. 


\section{Tabel 8 Rata-rata Gelombang Aktivitas Otak}

\begin{tabular}{ccc}
\hline $\begin{array}{c}\text { Jenis } \\
\text { Gelombang }\end{array}$ & \multicolumn{2}{c}{ Warna } \\
& Biru & Putih \\
\hline Meditation & 55,74 & 54,79 \\
Attention & 54,65 & 54,16 \\
\hline
\end{tabular}

Dapat dilihat dari Tabel 8 diatas, rata-rata gelombang meditation pada warna biru sebesar 55,74 dan 54,79 pada warna putih. Sedangkan untuk gelombang attention, memiliki rata-rata sebesar 54,65 pada warna biru dan 54,16 pada warna putih.

\section{KESIMPULAN}

Berdasarkan hasil evaluasi model struktural (inner model) faktor fisik terbukti berpengaruh positif terhadap faktor cognitive dengan nilai koefisien sebesar 0,202 dan signifikan pada 0,05 . Sehingga hasil pengujian hipotesis dalam penelitian ini dapat disimpulkan bahwa diterima.

Penelitian ini juga didukung hasil pengujian website menggunakkan alat "Neurosky Mindwave". Kelebihan pada penelitian ini, data terdiri dari 91 peserta, menguatkan hasil penelitian sebelumnya jika warna latar belakang biru bisa mempengaruhi kinerja otak dibandingkan dengan warna latar belakang putih (Yamazaki \& Eto, 2011), (Yamazaki \& Eto, 2012). Berikut hasil rata - rata gelombang aktivitas otak yaitu meditation warna biru 55,74 dan hasil meditation warna putih 54,79. Sedangkan hasil attention warna biru 54,65 dan attention warna putih 54,16. Kekurangan dalam penelitian ini, semua peserta adalah mahasiswa dan mahasiswi, berharap ke depan akan dilakukan penelitian lebih lanjut dengan target peserta yang berbeda seperti anak dengan autis, orang tua, dll.

\section{REFERENSI}

Ab Hamid, M. R., Sami, W., \& Sidek, M. M. (2017). Discriminant validity assessment: Use of Fornell \& Larcker criterion versus HTMT criterion. Journal of Physics: Conference Series, 890, 012163. IOP Publishing.

Bernardini, S., Porayska-Pomsta, K., \& Smith, T. J. (2014). ECHOES: An intelligent serious game for fostering social communication in children with autism. Information Sciences, 264, 41-60.

Bhattacharya, A., Gelsomini, M., Pérez-Fuster, P., Abowd, G. D., \& Rozga, A. (2015). Designing motion-based activities to engage students with autism in classroom settings. Proceedings of the 14th International Conference on Interaction Design and Children, 69-78. ACM.

Boyd, L. E., Rangel, A., Tomimbang, H., Conejo-Toledo, A., Patel, K., Tentori, M., \& Hayes, G. R. (2016). SayWAT: Augmenting Face-to-Face Conversations for Adults with Autism. Proceedings of the 2016 CHI Conference on Human Factors in Computing Systems, 4872-4883. ACM.

Caro, K., Tentori, M., Martínez-García, A. I., \& Zavala-Ibarra, I. (2015). FroggyBobby: An exergame to support children with motor problems practicing gross motor skills during therapeutic interventions. Journal of Computers in Human Behavior. 
Caro, Karina, Tentori, M., Martinez-Garcia, A. I., \& Alvelais, M. (2017). Using the FroggyBobby exergame to support eye-body coordination development of children with severe autism. International Journal of Human-Computer Studies, 105, 12-27.

Casas, X., Herrera, G., Coma, I., \& Fernández, M. (2012). A Kinect-based Augmented Reality System for Individuals with Autism Spectrum Disorders. Grapp/Ivapp, 440446.

Chien, M.-E., Jheng, C.-M., Lin, N.-M., Tang, H.-H., Taele, P., Tseng, W.-S., \& Chen, M. Y. (2015). iCAN: A tablet-based pedagogical system for improving communication skills of children with autism. International Journal of Human-Computer Studies, 73, 79-90.

Jang, Y. G., Kim, H. Y., \& Yi, M. K. (2007). A color contrast algorithm for e-learning standard. International Journal of Computer Science and Network Security, 74), 195-201.

Muggleton, N. G., Juan, C.-H., Cowey, A., Walsh, V., \& O'Breathnach, U. (2010). Human frontal eye fields and target switching. Cortex, 46(2), 178-184.

Rapp, A., Cena, F., Castaldo, R., Keller, R., \& Tirassa, M. (2018). Designing technology for spatial needs: Routines, control and social competences of people with autism. International Journal of Human-Computer Studies, 120, 49-65.

Tharangie, K. G. D., Irfan, C. M. A., Marasinghe, C. A., \& Yamada, K. (2008). Kansei Engineering Assessing System to enhance the usability in e-learning web interfaces: Colour basis. 16th International Conference on Computers in Education, 1, 145-150. Uzuegbunam, N., Wong, W.-H., Cheung, S. S., \& Ruble, L. (2015). MEBook: Kinectbased self-modeling intervention for children with autism. 2015 IEEE International Conference on Multimedia and Expo (ICME), 1-6. IEEE.

Yamazaki, A., \& Eto, K. (2012). An Analysis of white and blue background-color effects on the scores of Web-based English grammar tests using near-infrared spectroscopy. In Frontiers in Artificial Intelligence and Applications (pp. 911-920).

Yamazaki, A. K., \& Eto, K. (2011). A preliminary examination of background-color effects on the scores of computer-based english grammar tests using near-infrared spectroscopy. International Conference on Knowledge-Based and Intelligent Information and Engineering Systems, 31-39. Springer. 